Pesq. Vet. Bras. 35(1):9-12, janeiro 2015

DOI: 10.1590/S0100-736X2015000100003

\title{
Research of Klebsiella pneumoniae in dairy herds ${ }^{1}$
}

\author{
Helio Langoni ${ }^{2 *}$, Marcos Vinicius S. Guiduce ${ }^{2}$, Diego B. Nóbrega ${ }^{2}$, Rodrigo C. da \\ Silva², Virgínia B. Richini-Pereira $^{2}$, Anelise Salina ${ }^{2}$ and Felipe de F. Guimarães ${ }^{2}$
}

\begin{abstract}
Langoni H., Guiduce M.V.S., Nóbrega D.B., Silva R.C., Richini-Pereira V.B., Salina A. \& Guimarães F.F. 2015. Research of Klebsiella pneumoniae in dairy herds. Pesquisa Veterinária Brasileira 35(1):9-12. Departamento de Higiene Veterinária e Saúde Pública, Faculdade de Medicina Veterinária e Zootecnia, Universidade Estadual Paulista Júlio de Mesquita Filho, Campus de Botucatu, Distrito de Rubião Júnior s/n, Botucatu, SP 18618-970, Brazil. E-mail: hlangoni@fmvz.unesp.br

Klebsiella pneumoniae is a common environmental agent of clinical and subclinical mastitis affecting dairy herds, and may be present in the final product decreasing its quality. Mastitis caused by K. pneumoniae is even more severe due to its poor response to antibiotic therapy, rapid evolution to toxic shock and death of the animal. This paper aimed to study the prevalence of this pathogen among dairy herds in ten farms located in different municipalities of São Paulo State based on size and use of milking technology. All mammary glands of all lactating cows were screened using the California Mastitis Test (CMT) and a strip cup. A single aseptic milk sample $(20 \mathrm{~mL})$ was collected from all CMT-positive quarters and bulk tanks, whereas swab samples were collected from feces, hind limbs of the animals, bedding and milking parlor. Identification of K. pneumoniae was performed using conventional microbiology culture, biochemical assay and Polimerase Chain Reaction. The primers were designed and tested at the Laboratory of Molecular Biology applied to Zoonoses (FMVZ, Unesp-Botucatu) targeting the 16S rRNA gene. This study included 1067 animals. Six cases of intramammary infection by K. pneumoniae were detected in six different cows in two farms. Moreover, K. pneumoniae was isolated in 77 swabs ( 34 from bedding in 9 farms, 7 from waiting rooms in 5 farms, 6 from milking parlors in 4 farms, 11 from rectums in six farms, and 19 from hindlimbs in 7 farms. Molecular analysis confirmed the agent was K. pneumoniae. At least one strain of the agent was identified in a certain site in all farms, showing the need of maintaining the hygiene in dairy farms.
\end{abstract}

INDEX TERMS: Environment, Klebsiella pneumoniae, milk, mastitis, dairy herds.

RESUMO.- [Pesquisa de Klebsiella pneumoniae em rebanhos leiteiros.] Klebsiella pneumoniae é um agente ambiental comum de mastite clínica e subclínica que afetam vacas leiteiras e pode estar presente no produto final, reduzindo a sua qualidade. Mastite causada por K. pneumoniae é ainda mais grave devido à sua má resposta à antibioticoterapia, rápida evolução para choque tóxico e morte do animal. Este trabalho teve como objetivo estudar a prevalência deste patógeno entre os rebanhos leiteiros em dez fazendas localizadas em diferentes municípios do Estado de São Paulo

\footnotetext{
${ }^{1}$ Received on April 7, 2014.

Accepted for publication on October 20, 2014.

${ }^{2}$ Department of Veterinary Hygiene and Public Health, São Paulo State University (Unesp), Distrito de Rubião Junior s/n, Botucatu, SP 18618-970, Brazil. *Corresponding author. *Corresponding author: hlangoni@fmvz.unesp.br
}

com base no tamanho do rebanho e uso de tecnologia de ordenha. Todas as glândulas mamárias das vacas em lactação foram examinadas usando o California Mastitis Test (CMT) e caneca de fundo telado. Foram colhidas amostras de leite $(20 \mathrm{~mL})$ de todos os quartos CMT- positivos e dos tanques de expansão, também foram colhidos swab de fezes, membros posteriores dos animais, cama dos animais e sala de ordenha. $\mathrm{O}$ isolamento e identificação de $K$. pneumoniae foi realizada através de cultura microbiológica convencional, ensaio bioquímico e Reação em Cadeia da Polimerase, utilizando primers desenhados e testados no Laboratório de Biologia Molecular aplicada à Zoonoses (FMVZ, Unesp-Botucatu) com base na região do gene de 16S rRNA. Este estudo incluiu 1067 animais. Foram detectados seis casos de infecção intramamária por K. pneumoniae em seis dife- 
rentes animais em duas fazendas. Ainda, K. pneumoniae foi isolada em 77 swabs ( 34 de camas em 9 propriedades, 7 de salas de pré-ordenha em 5 propriedades, 6 de salas de ordenha em 4 propriedades, 11 do reto de animais em 6 propriedades e 19 de membros posteriores em 7 propriedades. A análise molecular confirmou o agente $K$. pneumoniae. $K$. pneumoniae foi isolada pelo menos em uma localização em todas as propriedades leiteiras., salientando a necessidade de manter a higiene nas fazendas leiteiras a fim de controlar a mastite por esse patógeno.

TERMOS DE INDEXAÇÃO: Ambiental, Klebsiella pneumoniae, leite, mastite, bovinos.

\section{INTRODUCTION}

Mastitis is the most frequent infectious disease that causes the greatest losses for dairy cattle (Langoni et al. 1998, Costa et al. 1999) and may be subclinically or clinically (Munoz et al. 2006). More than 100 microbial species were isolated from the mammary gland of cows; however, only a relatively small number is responsible for most mastitis cases which, according to the origin of the microorganism, are classified into contagious, when the bacterium lives primarily in the mammary gland, and environmental, when the microorganism is associated with the environment (Langoni 2013).

With the results of control programs for contagious mastitis (Staphylococcus aureus, Streptococcus agalactiae and Mycoplasma spp.), coagulase-negative Staphylococci (de Freitas Guimarães et al. 2013) and environmental mastitis (coliforms, fecal streptococci, Streptococcus dysgalactiae and Streptococcus uberis) has become the major form of the disease among dairy herds with low somatic cell count (SCC) in milk bulk tanks (Barkema et al. 1998).

In cases of clinical mastitis, gram-negative bacteria are most frequent, while Escherichia coli and Klebsiella spp. are most common (Munoz \& Zadoks 2007). The losses caused by Klebsiella spp. are more significant than those by E. coli considering milk production and animal survival (Munoz et al. 2006). Langoni et al. (1985) described a mastitis outbreak by Klebsiella pneumoniae involving a large number of animals.

Mastitis caused by K. pneumoniae is more severe due to its poor response to antibiotic therapy, rapid evolution to toxic shock and death of the animal (Silva \& Costa 2001, Ribeiro et al. 2008). The most effective strategy to control mastitis by coliforms is prevention by means of suitable management of the animals and the environment where they are kept, besides prophylactic immunization (Radostits et al. 2007).

Organic material bedding is a common source of teat contamination by environmental agents. Coliforms are essentially opportunistic pathogens, and their main reservoirs for transmission are feces, water and bedding material such as shavings or sawdust (Hogan et al. 2007, Nóbrega et al. 2013). Infected cows may manifest subclinical or clinical mastitis, showing changes in the milk, swollen quarter, anorexia and fever. Cows with subclinical mastitis do not show signs of the disease, which is detected only by laboratory tests (Paulin-Curlee et al. 2008).

The present paper aimed to study the prevalence of $K$. pneumoniae in different sources in ten dairy herds located in different municipalities of São Paulo State, based on phenotypic and genotypic techniques using samples of milk, feces, skin from hind limbs, milk from bulk tanks, and the environment where the animals were raised such as bedding and milking parlor.

\section{MATERIALS AND METHODS}

Herd selection and sampling strategy. A convenience sample of 10 dairy herds in São Paulo State was used. Herds were included in the study based on size (at least 50 lactating cows), use of milking technology (machine-milked cows), presence of their own bulk tank. Each farm was visited once during the study. All mammary glands of all lactating cows were screened using the California Mastitis Test (CMT) and a strip cup (Schalm \& Noorlander 1957). A single aseptic milk sample (20mL) was colleted from all CMT-positive quarters (even when visible abnormalities in milk were present) after udder preparation performed by farm personnel according. The samples stored in isothermal boxes under refrigeration.

For fecal sampling (RECT), six lactating cows were randomly chosen and a sterile swab was introduced into their rectum and carefully rubbed for 30 seconds on their rectal wall in several directions. The swabs were immediately stored in tubes containing $3.0 \mathrm{ml}$ sterile saline solution. Another six randomly chosen animals had samples collected from both hind limbs (HIND) by rubbing a swab in the proximal-distal direction for approximately 30 seconds. After collection, procedures were the same as previously described (NMC 1999).

To assess whether the bacteria was present in the raising environment, existence of free-stall barns was taken into consideration. Free-stall swabs were collected from bedding in extremities and central regions of both sides of the barn, totaling six bedding samples (ENV) from each farm. For farms without free stall, six samples were collected from sites of great agglomeration and sites of high humidity in the paddocks of the animals. In all these cases, the swabs were rubbed for around 30 seconds in circular movements on an area of approximately $400 \mathrm{~cm}^{2}$ and stored as previously mentioned. Swabs were also collected from milking parlor (MP) (entrance and exit of the room, totaling 2 swabs) and from waiting room (WR) (superior and inferior part).

From the bulk tank (TANK), a 30ml milk sample was collected, after adequate homogenization, using previously sterilized ladle and glass flask. The samples were transported under refrigeration.

Laboratory methods. For milk samples, $0.01 \mathrm{~mL}$ was cultured in blood agar medium added of $8 \%$ ovine blood and MacConkey agar, adopting the streaking technique; the plates were divided into four quadrants and incubated for up to 96 hours, while microbial growth was observed at every 24 hours for the research of Klebsiella spp. The samples were considered contaminated when more than three types of colonies were isolated (National Mastitis Council 1999).

For each swab sample, $10^{-1}, 10^{-2}, 10^{-3}$ dilutions were prepared in sterile saline. After homogenization, $0.1 \mathrm{ml}$ from each dilution was cultured in MacConkey Agar containing 10mg/L ampicillin per liter of culture medium under incubation for 24 hours at $37^{\circ} \mathrm{C}$. According to Munoz et al. (2006), this ampicillin level allows the growth of bacteria of the genus Klebsiella spp. and inhibits the growth of most E. coli.

Specifically for suggestive cases of Klebsiella spp. isolation (pink coloration, 1-to-7mm diameter, mucus production), the colonies were recultured in brain-heart infusion (BHI) added of $4 \%$ glycerol and stored at $-80^{\circ} \mathrm{C}$ for biochemical characterization. For identification, they were reisolated and subjected to bioche- 
mical assay (EPM, MILI and Simmons Citrate). Klebsiella isolates showed negative motility and positive citrate. The indole assay differentiates $K$. pneumoniae and $K$. oxytoca into indole-negative and indole-positive, respectively. Other biochemical assays were employed according to Quinn et al. (2005) in cases of doubt.

Molecular analysis. $K$. pneumoniae DNA was extracted by using the kit Illustra Blood GenomicPrep Mini Spin ${ }^{\circledR}$ (GE Healthcare). Amplification was done with primers Kpn1 (5'- CAGCCACACTGGAACTGAGA -3') and Kpn2 (5'- GTTAGCCGGTGCTTCTTCTG $\left.-3^{\prime}\right)$. These primers were designed and tested in the Laboratory of Molecular Biology applied to Zoonoses (FMVZ, Unesp-Botucatu) targeting the $16 \mathrm{~S}$ rRNA gene; the analyses were carried out by using the computer programs Primer3 and PrimerBLAST with 342-bp product.

PCR reactions were performed with $10 \mathrm{pmol}$ of each primer (Integrated DNA Technologies, USA), 1.0U Taq Platinum DNA polymerase (Invitrogen, USA), $200 \mu \mathrm{M}$ dNTP, PCR buffer $1 \mathrm{x}, 0.75$ $\mathrm{mM} \mathrm{MgCl}_{2}$ and $3 \mu \mathrm{L}$ of the sample. E. coli DNA (ATCC 25922-Fiocruz INCQS) and ultrapure water were used as negative controls. K. pneumoniae DNA (ATCC 13883-Fiocruz INCQS) was used as positive control. The incubation was carried out in a thermocycler Mastercycler EP gradient (Eppendorf, USA). The cycling profile was: $94^{\circ}$ for $4 \mathrm{~min}$, followed by 35 cycles of $94^{\circ} \mathrm{C}$ for $1 \mathrm{~min}, 60^{\circ} \mathrm{C}$ for $1 \mathrm{~min}, 72^{\circ} \mathrm{C}$ for $1 \mathrm{~min}$, and final extension of $72^{\circ} \mathrm{C}$ for $10 \mathrm{~min}$. PCR products were visualized in $1.5 \%$ agarose gel. Amplicons were purified by using ExoSap (USB, USA). The sequencer 3500 Genetic Analyser (Life Technologies, USA) was employed. The obtained sequences were visualized using Chromas 2.3 (Technelysium Pty Ltd, Australia) and aligned with the software Mega4 (Tamura et al. 2007), compared with the sequences stored at NCBI database using BLASTn (Basic Local Alignment Tool for Nucleotide).

Statistical analysis. For statistical analysis, the frequencies of K. pneumoniae isolation from bedding, rectum, hind limbs, milk from the animals and the tanks were calculated and intramammary infection (IMI) was defined as the isolation of a microorganism from the milk sample (teal level), or bacteria isolation of at least one teat per animal (animal-level).

\section{RESULTS}

4268 teats from 1067 cows were enrolled in the study. According to CMT results, $2828(66.26 \%)$ assessed teats score as one, while 237 (5.55\%) were scored as two, 300 $(7.03 \%)$ were scored as three and 730 teats $(17.1 \%)$ were scored four in a 4-point scale (de Pinho Manzi et al. 2012); 25 teats had clinical mastitis and 148 were considered lost. As to mammary gland health, 3619 teats did not have IMI and $649(15.21 \%)$ were infected; being 142 cases caused by environmental agents, and in 6 teats $(0.92 \%)$ K. pneumoniae was isolated. Other pathogens showing high isolation frequency (excluding contaminated milk and CMT-negative samples) were Corynebacterium bovis (215 cases, 33.33\% isolated agents), Staphylococcus spp. (214, 32.97\%), environmental Streptococcus $(96,14.79 \%)$ and S. agalactiae (73, 11.25\%).

Regarding the farms results ranged from $0.85 \%$ to $33.33 \%$ and from 4.31 to $29.99 \%$ (teat and animal-level respectively) of IMI cases caused by environmental pathogens.

Considering the animal as an experimental unit, 419 $(39.27 \%)$ had at least one teat with IMI. One-hundred and seventeen showed isolation of environmental pathogens in at least one mammary quarter. Six animals had at least one teat infected by $K$. pneumoniae. Among the main isolated pathogens are Staphylococcus spp. (142 animals, 33.89\%), C. bovis $(115,27.45 \%)$, environmental Streptococcus (60, $14.32 \%)$ and S. agalactiae (41, 9.79\%).

K. pneumoniae was isolated from six IMI cases from two farms only, accounting for $20 \%$ of the studied farms. Also, it was isolated in 77 swabs ( 34 from environments in 9 farms, 7 from waiting rooms in 5 farms, 6 from milking parlors in 4 farms, 11 from rectums in six farms, and 19 from hind limbs in 7 farms.

$K$. pneumoniae isolation according to sample location and number of farms where the bacteria was isolated is shown in Table 1.

As to the sequencing, the obtained sequences were analyzed and compared with those stored at GenBank. The molecular identity of all samples resulted in $100 \%$ similarity with K. pneumoniae (GenBank AB675600.1).

\section{Table 1. Absolute frequency of $K$. pneumoniae isolated from ten dairy farms (N) and number of farms (NF) with at least, one $K$. pneumoniae positive swab isolated from that specific sample. Botucatu, Sao Paulo State, Brazil, 2013}

\begin{tabular}{lcc}
\hline Sample & N & NF \\
\hline Rectum of cows & 11 & 6 \\
Hind limbs & 19 & 7 \\
Environment & 34 & 9 \\
Milking parlor & 6 & 4 \\
Waiting room & 7 & 5 \\
Tank & 4 & 4 \\
Intramammary infection & 6 & 2
\end{tabular}

\section{DISCUSSION}

In the present study, $15.21 \%$ IMI cases were detected considering the result of CMT, and most of them were caused by contagious pathogens. Contagious mastitis has undergone a significant global reduction in its frequency during the last decades (Shum et al. 2009) due to implementation of strict control programs, which may lead to an increase in the number of cases of environmental mastitis (Breen et al. 2009). In spite of this concept, special attention has been given to emerging pathogens, which remain the focus of several studies (Pyorala \& Taponem 2009).

There was a great variation among farms as to the frequency of IMI caused by environmental pathogens, from $0.85 \%$ to $33.33 \%$. The raising systems, the hygiene (Fregonesi et al. 2009) and the implementation of control programs are responsible for the great variability in the obtained results. The percentage of IMI animals was also highly variable, ranging from $4.31 \%$ to $29.99 \%$. These data are relevant for the prophylaxis and control of mastitis, for which hygienic aspects related to cleaning the environment of each animal and the teats in both pre- and post-milking are already established and must be part of any program for mastitis control.

Around $40 \%$ animals had IMI in at least one teat, of which $10 \%$ cases were caused by environmental pathogens, corresponding to approximately $25 \%$ of the detected IMI. This number is highly expressive, considering that most pathogens are contagious. Although environmental pathogens were isolated at a lower frequency, they affect a large number of animals, probably without concomitance in all four teats, differently from contagious ones, which in the 
majority of cases infect more than one teat and even all four teats. This contributes to better understand the epidemiological aspects of mastitis, evidencing the importance of adopting effective control measures.

$K$. pneumoniae was detected in all farms in the present study in at least one swab collection site. This result is a cause of concern since it indicates the presence of this bacteria in the environment of animals and in sites like bulk tank, milking parlor and hind limbs. Pathogens isolated from sites like the hind limbs of animals may reach the udder of cows and, via the lactiferous duct, originate IMI, leading to losses in milk production and quality, as well as to public health problems due to the presence of these agents in milk for consumption. Another significant aspect for public health is the possible occurrence of strains that are multi-resistant to antimicrobials administered for both animals and men.

Curiously, in two farms where were detected IMI cases caused by K. pneumoniae, the pathogen was also detected in the bulk tank. The bacteria from IMI cases may be responsible for contaminating the milk in the tank.

Another important aspect observed in the present study was the relationship between the raising system and the isolation or not of the agent; all IMI cases were detected in animals kept in free-stall system. Farms that adopt this system generally have a higher productive capacity and more rigorous hygiene and mastitis control procedures, which leads to a more efficient control of contagious mastitis, predisposing to environmental mastitis; this has been observed worldwide in farms with excellent infrastructure where contagious mastitis, especially those caused by $S$. agalactiae and $S$. aureus was controlled.

As regards molecular analysis, samples were confirmed as K. pneumoniae, showing high specificity of primers; however, it was not possible to identify differences in sequences since the primers employed in the sequencing were from a conserved region of the 16S rRNA genome; thus, the phylogenetic analysis could not be carried out. Complementary studies using polymorphic regions which differentiate small genetic changes will be needed to obtain phylogenetic trees with the aim of differentiating molecular profiles that will help in the preparation of strategies to reduce infection in certain farms.

\section{CONCLUSION}

Klebsiella pneumoniae is present in the raising environment of cattle and not only in feces. Cases of IMI by this pathogen are less frequent; however, control of contagious pathogens is known to make environmental ones more prevalent, which may become cause of concern for milk producers in future.

Acknowledgements.- This study was funded by FAPESP (The São Paulo State Official Foundation to Support Research) M.V.S. Guiduce (Grant 2009/10864-7) for the grant and the financial received for this research.

\section{REFERENCES}

Barkema H.W., Schukken Y.H., Lam T.J.G.M., Beiboer M.L., Benedictus G. \& Brand A. 1998. Management Practices Associated with Low, Medium, and High Somatic Cell Counts in Bulk Milk. J. Dairy Sci. 81(7):1917-1927.

Breen J.E., Green M.J. \& Bradley A. J. 2009. Quarter and cow risk factors associated with the occurrence of clinical mastitis in dairy cows in the United Kingdom. J. Dairy Sci. 92(6):2551-2561.

Costa E.O., Ribeiro A.R., Watanabe E.T., Silva J.A.B., Garino-Junior F., Benites N.R. \& Horiuti A.M. 1999. Mastite subclínica: prejuízos causados e os custos de prevenção em propriedades leiteiras. Revta Nap Gama 2(2):16-20.

de Freitas Guimarães F., Nóbrega D.B., Richini-Pereira V.B., Marson P.M., De Figueiredo Pantoja J.C. \& Langoni H. 2013. Enterotoxin genes in coagulase-negative and coagulase-positive staphylococci isolated from bovine milk. J. Dairy Sci. 96:2866-2872.

de Pinho Manzi M., Nóbrega D.B., Faccioli P.Y., Troncarelli M.Z., Menozzi B.D. \& Langoni H. 2012. Relationship between teat-end condition, udder cleanliness and bovine subclinical mastitis. Res. Vet. Sci. 93(1):430-434

Fregonesi J.A., Von Keyserlingk M.A., Tucker C. B., Veira D. M. \& Weary D.M. 2009. Neck-rail position in the free stall affects standing behavior and udder and stall cleanliness. J. Dairy Sci. 92(5):1979-1985.

Hogan J.S., Wolf S.L. \& Pettersson-Wolfe C.S. 2007. Bacterial Counts in Organic Materials Used as Free-Stall Bedding Following Treatment with a Commercial Conditioner. J. Dairy Sci. 90:1058-1062.

Langoni H., Corrêa C.N.M., Corrêa W.M., Barros J.A. \& Corrêa G.N. 1985. Mastites bovinas por Candida e Klebsiella. Revta Bras. Med. Vet. 7(7): 203-204.

Langoni H., Silva A.V., Cabral K.G. \& Domingues P.F. 1998. Aspectos etiológicos na mastite bovina: flora bacteriana aeróbica. Revta Bras. Med. Vet. 20(5):204-209.

Langoni H. 2013. Qualidade do leite: utopia sem um programa sério de monitoramento da ocorrência de mastite bovina. Pesq. Vet. Bras. 33(5): 620-626.

Munoz M.A., Ahlstrom C., Rauch B.J. \& Zadoks R.N. 2006. Fecal shedding of Klebsiella pneumoniae by dairy cows. J. Dairy Sci. 89:3425-3430.

Munoz M.A. \& Zadoks R.N. 2007. Patterns of fecal shedding of Klebsiella by dairy cows. J. Dairy Sci. 90:1220-1224.

National Mastitis Council 1999. Laboratory Handbook on Bovine Mastitis. National Mastitis Council, Madison, WI.

Nóbrega D.B., Guiduce M.V.S., Guimarães F.F., Riboli D.F., Cunha M.L.R.S., Langoni H., Pantoja J.C.F. \& Lucheis S.B. 2013. Molecular epidemiology and extended-spectrum $\beta$-lactamases production of Klebsiella pneumoniae isolated from three dairy herds. Pesq. Vet. Bras. 33:855-859.

Paulin-Curlee G.G., Sreevatsan S., Singer R.S., Isaacson R., Reneau J., Bey R. \& Foster D. 2008. Molecular Subtyping of Mastitis-Associated Klebsiella pneumonia Isolates Shows High Levels of Diversity Within and Between Dairy Herds. J. Dairy Sci. 91:554-563.

Pyorala S. \& Taponen S. 2009. Coagulase-negative staphylococci-emerging mastitis pathogens. Vet. Microbiol. 134(1/2):3-8.

Quinn P.J., Markey B., Carter M.E., Donnelly W.J. \& Leonard F.C. 2005. Microbiologia Veterinária e Doenças Infecciosas. Artmed, Porto Alegre.

Radostits O.M., Gay C.C., Hinchcliff K.W. \& Constable P.D. 2007. Veterinary Medicine. $10^{\text {th }}$ ed. Saunders Elsevier, USA. 2156p.

Ribeiro M.G., Motta R.G., Paes A.C., Allendorf S.D., Salerno T., Siqueira A.K., Fernandes M.C. \& Lara G.H.B. 2008. Peracute bovine mastitis caused by Klebsiella pneumoniae. Arq. Bras. Med. Vet. Zootec. 60(2):485-488.

SAS Institute 2008. SAS/STAT User's Guide. Version 9.2. SAS Incorporation., Cary, NC.

Schalm O.W. \& Noorlander D.O. 1957. Experiments and observation leading to development of California Mastitis Test. J. Am. Vet. Assoc. 130: 199-204.

Shum L.W., McConnel C.S., Gunn A.A. \& House J.K. 2009. Environmental mastitis in intensive high-producing dairy herds in New South Wales. Aust Vet J. 87(12):469-475.

Silva N. \& Costa G.M. 2001. An outbreak of acute bovine mastitis caused by Klebsiella pneumoniae in a dairy herd. Arq. Bras. Med. Vet. Zootec.. 53(4):1-5.

Tamura K., Dudley J., Nei M. \& Kumar S. 2007. MEGA4: molecular evolutionary genetics analysis (MEGA) software version 4.0. Molec. Biol. Evol. 24:1596-1599. 